\title{
Near infrared reflectance spectroscopy (NIRS) for predicting forage quality of perennial warm-season grasses in La Pampa, Argentina
}

\author{
CM Rabotnikof 1, GM Planas 2, J Silva Colomer ${ }^{1}$, NP Stritzler 1 \\ ${ }^{1}$ Facultad de Agronomía, Universidad Nacional de La Pampa, PO Box 300 , \\ 6300 Santa Rosa, La Pampa; \\ 2 Laquige, CONICET, Juan Ramírez Velazco 847, 1414 Buenos Aires, Argentina
}

(Received 16 May 1991; accepted 16 March 1994)

\begin{abstract}
Summary - The aim of this study was to evaluate the relationship between NIRS and wet chemistry analysis for in vitro dry matter digestibility (IVDMD), crude protein (CP), neutral detergent fibre (NDF) and lignin. An Infra Alyzer 2.5 Plus (Technicon, New York, USA) interphased to a Hewlett Packard 9815A computer was calibrated for IVDMD, CP, NDF and lignin through 6 different wavelengths, all in the near infrared region. A total of 75 samples of standing, dead, above-ground biomass of warm-season grasses (Bothriochloa bladii, Digitaria eriantha ssp eriantha, Eragrostis curvula cvs Don Eduardo and Tanganika and Panicum antidotale) were analyzed. Correlations coefficients obtained during validation were high for IVDMD $\left(R^{2}=0.827 ; \mathrm{SE}=1.33\right)$ and $\mathrm{CP}\left(R^{2}=0.918 ; \mathrm{SE}=0.31\right)$; medium for lignin $\left(R^{2}=0.593 ; \mathrm{SE}=0.71\right)$ and low for $\mathrm{NDF}\left(R^{2}=0.285 ; \mathrm{SE}=2.49\right)$.
\end{abstract}

\section{NIRS / correlation coefficients / Warm-season grasses / Argentina}

Résumé - Spectroscopie par réflectance dans le proche infrarouge pour la prévision de la valeur alimentaire de Graminées pérennes à croissance estivale, cultivées à La Pampa, Argentine. Le but de ce travail a été de déterminer les corrélations entre les mesures obtenues par SPIR et les résultats de certaines analyses chimiques telles que la digestibilité in vitro de la matière sèche (DIVMS), la teneur en matières azotées totales (MAT), les parois végétales (NDF) et la lignine. Un appareil Infra Alyzer 2.5 Plus (Technicon, New York), connecté à un ordinateur Hewlett Packard, modèle $9815 \mathrm{~A}$, a été réglé pour 6 longueurs d'ondes différentes dans le spectre du proche infrarouge. Soixante quinze échantillons de pailles sur pied de Graminées pérennes à croissance estivale ont été mesurés par SPIR. Les échantillons comprenaient: Bothriochloa bladii, Digitaria eriantha ssp eriantha, Eragrostis curvula cvs Don Eduardo et Tanganika et Panicum antidotale. Les coefficients de corrélation ont été élevés pour DIVMS $\left(\mathrm{R}^{2}=0,827 ; \mathrm{Sr}=1,33\right)$ et pour MAT $\left(\mathrm{R}^{2}=0,918 ; \mathrm{Sr}=0,31\right)$; moyens pour lignine $\left(\mathrm{R}^{2}=0,593 ; \mathrm{Sr}=0,71\right)$ et faibles pour $\mathrm{NDF}\left(\mathrm{R}^{2}=0,285 ; \mathrm{Sr}=2,49\right)$. 


\section{INTRODUCTION}

The most interesting technique at the present for the prediction of food quality is infrared spectroscopy particularly in the near infrared (NIRS), as demonstrated by Norris et al (1976).

Several warm-season grasses are becoming an important feed resource for ruminants in the semi-arid area of $\mathrm{La}$ Pampa, Argentina, where not so long ago the only species of this type under research and production was weeping lovegrass (Eragrostis curvula). The strict rainfall regime of this region, with a very dry winter, makes the search for a relatively low cost feed resource for pregnant cows during winter very important.

Although a good prediction of quality parameters is generally reached with NIRS, some authors have questioned its reliability when analyses are performed across different plant species and cultivars (Marten et al, 1983; Lutz et al, 1984).

The aim of the present study was to determine the ability of NIRS to predict the chemical composition and the in vitro digestibility of standing, dead material from 5 different warm-season grasses grown in the semiarid region of La Pampa, Argentina.

\section{MATERIALS AND METHODS}

The samples analyzed in this study came from the winter harvested forages of warm-season grasses, produced during the whole growing season.

The species evaluated were Bothriochloa bladii, Digitaria eriantha ssp eriantha, Eragrostis curvula cv Don Eduardo and Tanganyka and Panicum antidotale. Fifteen samples of each species ( 5 cutting dates with 3 replications each in a randomized block design) were collected, making up a total of 75 samples. The cutting dates were March 17, May 2, June 16, August 2 and September 15,1985 . The samples were dried at $65^{\circ} \mathrm{C}$ for $72 \mathrm{~h}$, ground through a 1-mm screen and pro- cessed for: a) in vitro dry matter digestibility (IVDMO) (Tilley and Terry, 1963); b) crude protein (CP) content $(\mathrm{N} \times 6.25)$; c) cell-wall content (Goering and Van Soest, 1970); and d) lignin content (Christian, 1971).

NIRS measurements were made using an 'Infra Alyzer 2.5 Plus' (Technicon, New York), interphased to a Hewlett Packard 9815 A computer. This system collects the values as the log of the inverse of the reflectance $(\log (1 / R))$, and data were recorded as such. All values were then transformed to the second derivative and incorporated into the computer program for further statistical analysis. All data were analyzed by using the second derivative transformation; the NIRS data, after their transformation, were related to those obtained by wet chemistry, by stepwise multiple regression analysis. The system was calibrated by reading 26 samples on the 6 different wavelengths available $(1680,1940,2100$, 2180,2230 and $2310 \mathrm{~nm}$ ) in the NIRS instrument used. Some of these samples $(n=11-15)$ were used to obtain the prediction equations by NIRS, chosen by goodness of fit between wet chemistry and derivatized reflectance data, but covering the whole range of values. The 26 samples were then read again to complete the validation process. Once the calibration equations were obtained, 49 additional samples were tested by NIRS, in order to calculate the predictive value of NIRS for each parameter.

\section{RESULTS AND DISCUSSION}

The multiple correlation coefficients and standard errors (SEC) of calibration are shown in table I. The statistical treatment of the calibration data included large $R^{2}$ and low SEC, except for digestibility (SEC = 1.14). The calibration equations were then tested for internal validation on the same 26 samples by simple regression analysis; the standard errors (SEV) were low for all parameters, but $R^{2}$ of NDF and lignin were lower than those obtained with the calibration set. This first validation suggests a low ability of NIRS for the prediction of these 2 forage components.

For IVDMD and $\mathrm{CP}$, the validation values of $R^{2}$ and standard error were similar to 
Table I. Mean values obtained by wet chemistry and NIRS correlation coefficients for calibration and internal validation.

\begin{tabular}{|c|c|c|c|c|c|c|c|c|}
\hline \multirow{2}{*}{$\begin{array}{l}\text { Chemical } \\
\text { analyses }\end{array}$} & \multirow[t]{2}{*}{$\angle A B$ a } & \multirow[t]{2}{*}{ Range $b$} & \multirow[t]{2}{*}{ NIRSc } & \multicolumn{2}{|c|}{ Calibration $\mathrm{d}$} & \multirow[t]{2}{*}{ Bias $^{e}$} & \multicolumn{2}{|c|}{ Internal validation } \\
\hline & & & & $\mathrm{R}^{2}$ & $S E C$ & & SEV & $\mathrm{R}^{2}$ \\
\hline$\%$ IVDMD & 43.33 & $22.20-56.18$ & 43.34 & 0.967 & 1.14 & 0.01 & 0.909 & 1.61 \\
\hline$\%$ Protein & 3.65 & $2.44-8.04$ & 3.70 & 0.901 & 0.31 & 0.05 & 0.921 & 0.23 \\
\hline$\%$ Lignin & 11.23 & $8.24-13.12$ & 11.18 & 0.927 & 0.21 & 0.05 & 0.638 & 0.29 \\
\hline$\%$ NDF & 78.82 & $71.82-83.82$ & 78.75 & 0.938 & 0.43 & 0.07 & 0.656 & 0.55 \\
\hline
\end{tabular}

a Mean values for wet chemistry analyses; $\mathrm{b}$ according to wet chemistry analyses; ${ }^{c}$ mean value for NIRS; d multiple correlation coefficients $\left(F^{2}\right)$ and standard error for calibration (SEC); e difference between mean LAB and mean NIRS values; ${ }^{f}$ simple correlation coefficients $\left(R^{2}\right)$ and standard error for internal validation (SEV).

those of the calibration equations, and are in good agreement with those reported in the literature (Planas and Crespi, 1984; Shenk, 1989).

The equations were used to further validate NIRS values against wet chemistry data by simple regression analysis for 49 additional samples, which were not used for calibration. The statistical results are shown in table II. The $R^{2}$ value of prediction for CP was similar to that of internal validation, and the standard error (SEP), not corrected for bias, was slightly higher. For IVDMD, $R^{2}$ was lower than $R^{2}$ for internal validation, but still high, and SEP was also slightly higher (tables I and II).

The predictive ability of NIRS dropped dramatically for neutral detergent fibre (NDF) (tables I and II); the $R^{2}$ was low and the standard error was obviously higher when compared to SEV. The $R^{2}$ of prediction for lignin was only slightly lower than the $R^{2}$ of internal validation and the SEP, although higher than SEV, was still low. The narrow range in NDF and lignin concentrations in the forages might have been a contributing factor to the poor predictions by NIRS.

Table II. Mean values obtained by wet chemistry and NIRS, and correlation coefficients for prediction.

\begin{tabular}{|c|c|c|c|c|c|c|c|}
\hline \multirow{2}{*}{$\begin{array}{l}\text { Chemical } \\
\text { analysis }\end{array}$} & \multirow{2}{*}{$\begin{array}{l}\text { Number of } \\
\text { samples a }\end{array}$} & $\angle A B$ b & Range $\mathrm{c}$ & NIRS ${ }^{d}$ & Bias $^{\mathrm{e}}$ & \multicolumn{2}{|c|}{ Prediction $^{\dagger}$} \\
\hline & & & & & & $\mathrm{R}^{2}$ & SEP \\
\hline$\%$ IVDMD & 49 & 39.70 & $22.20-57.96$ & 41.87 & 2.17 & 0.827 & 1.33 \\
\hline$\%$ Protein & 49 & 4.10 & $2.44-8.04$ & 4.13 & 0.03 & 0.918 & 0.31 \\
\hline$\%$ Lignin & 49 & 10.97 & $8.24-13.37$ & 11.04 & 0.07 & 0.591 & 0.71 \\
\hline$\%$ NDF & 49 & 77.78 & $71.82-83.82$ & 77.94 & 0.16 & 0.285 & 2.49 \\
\hline
\end{tabular}

a Number of samples processed in the general validation (prediction); $b$ mean value for wet chemistry analyses; $c$ according to wet chemistry analyses; d mean value for NIRS; ${ }^{e}$ difference between mean LAB and mean NIRS values; ${ }^{\dagger}$ simple correlation coefficients $R^{2}$ and standard error for prediction (SEP). 
The predictions of chemical values obtained by NIRS in this study were valid, similar to those found by Lutz et al (1984). These authors suggested that one reason for the high $R^{2}$ found in their research could be that they used only one species and cultivar (Eragrostis curvula cv Tanganyka). In the present study, however, the results were similar, although the number of species and cultivars was widened. Nonetheless, the development of equations for each species may enhance the prediction ability of NIRS.

\section{CONCLUSIONS}

The use of NIRS instrument with filters and the relatively low number of samples used in this study could have influenced the precision of the prediction equations. The use of a scanning instrument might help to improve the results. NIRS, however, predicts accurately the in vitro digestibility and $\mathrm{CP}$ content of warm-season grasses grown in semi-arid conditions. The technique has some potential for the prediction of lignin content, but not for NDF, at least under the conditions of this study. NIRS, therefore, could play a very important role in the comparative evaluation of some quality parameters of large numbers of warm-season grasses recently introduced in La Pampa, Argentina.

\section{REFERENCES}

Christian K (1971) Detergent method for total lignin in herbage. Fed Stn Res Div PI Ind CSIRO (Aust) 10, 29-34

Goering HK, Van Soest PJ (1970) Forage fiber analysis (apparatus, reagents, procedures and some applications). Agric Handbook No 379 ARS Dep Agric, USA

Lutz EE, Torres MB, Salguez ML, Arelovich HM, Herrero JC (1984) Proteina, pared celular y digestibilidad in vitro en pasto llorón (Eragrostis curvula) por reflectancia de rayos infra-rojos. Rev Arg Prod Anim 4, 423-429

Marten GC, Halgerson JL, Cherney JH (1983) Quality prediction of small grain forages by near infrared reflectance spectroscopy. Crop Sci 23, 94-96

Norris KH, Barnes RF, Moore JE, Shenk JS (1976) Predicting forage quality by infrared reflectance spectroscopy. J Anim Sci 43, 889-897

Planas GM, Crespi DLG (1984) Digestibilidad y proteína en forrajeras por reflectancia de infra-rojo cercano. Rev Arg Prod Anim 4, 273-278

Shenk JS (1989) Near infrared reflectance spectroscopy as an analytical tool for world agriculture. $X V I$ int Grassid Congress Nice, France, 883-884

Tilley JMA, Terry RA (1963) A two-stage technique for the in vitro digestion of forage crops. $\mathrm{J} \mathrm{Br}$ Grassld Soc $18,104-111$ 